\title{
Usability Issues in Mobile-Wireless Information Systems
}

\author{
Ruti Gafni \\ The Open University of Israel, Israel
}

rutiga@openu.ac.il

\begin{abstract}
Usability is one of the characteristics that compose the multi-dimension concept of information systems' quality. Technology improvements enable the building of information systems to be used "any place, any time", through mobile handheld devices and wireless networks. Usability is threatened by the use of mobile-wire less information systems, especially because of the use of small devices with tiny screens, the difficulty to operate and the use during mobility. Therefore, there is a need to measure the usability characteristic, in order to define the level of quality of such information systems. This paper introduces the definitions of usability, and presents the definition of new metrics, defined in order to measure the quality level of usability of mobilewireless information systems. These metrics were empirically validated using four different experiments, based on handheld devices.
\end{abstract}

Ke ywords: usability, information systems, mobile, wireless, qua lity.

\section{Introduction}

The evolution of technology in the fields of handheld devices like cellular phones, personal digital assistants (PDA) and smart-phones and in the field of wire less communications increased the development of mobile-wireless information systems, which can be used ubiquitously.

Mobile-wireless information systems can create benefits for organizations; such as productivity enhancement, processes and procedures flexibility, customer services improvement and information accuracy for decision makers, which together emphasize competitive strategy, lower operation costs, and improved processes (Lau, 2006; Lee, 2003; Lovell, 1995). But, on the other hand, they face new kinds of problems: narrow bands, small devices, tiny screens and diversity of users and devices. These problems threaten the quality of such systems (Terho, 2002), including the usability quality characteristic, which is one of the characteristics that compose the multidimension concept of information systems' quality.

Research on quality of information systems has been focused on traditional (Kan, 2002) and internet information systems (Calero,

Material published as part of this publication, either on-line or in print, is copyrighted by the Informing Science Institute. Permission to make digital or paper copy of part or all of these works for personal or classroom use is granted without fee provided that the copies are not made or distributed for profit or commercial advantage AND that copies 1) bear this notice in full and 2) give the full citation on the first page. It is permissible to abstract these works so long as credit is given. To copy in all other cases or to republish or to post on a server or to redistribute to lists requires specific permission and payment of a fee. Contact Publisher@InformingScience.org to request redistribution permission. Ruiz, \& Piattini, 2004; Covella \& Olsina, 2006). The special mobile-wireless information systems characteristics require a different quality definition.

In order to define the level of quality of a mobile-wire less information system, there is a need to measure, among others, the usability characteristic. This paper introduces the various definitions of usability and presents new metrics, de- 
fined according to Gafni's methodology (2008), to measure the usability of mobile-wire less information systems. The metrics were defined and empirically validated.

\section{Mobile-Wireless Information Systems}

Schiller (2000) describes two mobility dimensions: user mobility which allows connection to the system from different geographical sites and device mobility which enables mobility of both user and system. This research focuses on mobile-wireless information systems, allowing the users to be connected any time at any place, using handhe ld devices such as PDAs or cellular phones connected via a wireless network.

There are two classifications of mobile-wire less applications: horizontal and vertical (Stafford \& Gillenson, 2003). Horizontal applications are general, adaptable to a wide range of users and organizations, e.g.: e-mail, browsers, and file transfer applications. Vertical applications are specific to a type of users or organizations, for example: financial applications, such as money transfer, stock exchange and information inquiry; marketing and advertising applications according to the actual user position, i.e., pushing coupons to stores and information about sales nearby; emergency applications to check real-time information from government and medical databases and utility companies applications used by technicians and meter readers.

There were unsuccessful attempts to develop mobile-wireless information systems at the beginning of the millennium, since technology, devices and infrastructures were immature (Sult \& Lee, 2003). This situation changed during 2003, and analysts agreed that this kind of systems will grow and their market share will expand (Lau, 2006; Lee, 2003). The major reasons are emergence of third generation wireless networks (Universal Mobile Telecommunications System [UMTS], Code divis ion multiple access [CDMA2000 1x] and General Packet Radio Service [GPRS]), their coverage expansion and deve lopment of smart mobile devices.

There are several advantages of using these systems in the place and time of the event occurrence, in particular, productivity enhancement, resource allocation flexibility, competitive advantages, service improvements and information accuracy (Malladi \& Agrawal, 2002).

\section{Usability - A Measurable Quality Characteristic}

Measuring creates a quantitative description which allows behavior comprehension and enables selection of tools and techniques to control and improve processes, products and resources. Information systems quality cannot be measured only by software faults absence; it must be broader. In fact, quality is a multi-dimension concept which includes a multitude of characteristics to cover all aspects, life-cycle phases and viewpoints. Several attempts have been made to examine the information systems quality nature, to define quality components and to find systematic ways to measure them (Boehm, Brown, Kaspar, Lipow, \& McCleod, 1978; ISO/IEC 9126-1, 2001; Kan, 2002; McCall, Richards \&, Walters, 1977; Pandian, 2004).

One of the characteristics included in all quality standards and definitions, accepted by all researchers is "usability", which was originally derived from the term "user friendly". However, there is no consistency in the definition of the meaning of usability and its decomposition into sub-characteristics.

\section{The Definition of Usability}

Different standards define usability in different ways, for example:

- "The ease with which a user can learn to operate, prepare inputs for, and interpret outputs of a system or component." (IEEE1061, 1992) 
- "The extent to which a product can be used by specified users to achieve specified goals with effectiveness, efficiency, and satisfaction in a specified context of use." (ISO9241$11,1998)$

- "The capability of the software product to be understood, learned, used, and attractive to the user, when used under specified conditions." (ISO9126-1, 2001)

These and other definitions, make it difficult to specify the measurable usability attributes and their interpretations from different points of views (Seffah \& Metzker, 2004). For example, for the end user, software usability is essential because it measures user performance, satisfaction, and productivity. An application that features good usability will allow the user to perform the expected tasks more efficiently. For managers, usability is a major decision factor, particularly for selecting a product. Therefore, it has a direct influence on the organizational productivity and performance. For software developers, usability can be described in terms of internal attributes of a system that affect user performance and productivity. These viewpoints have led to different definitions of usability in various standards, although one function of standards is to impose consistency (Bevan, 2001).

ISO/IEC 9126 is a standard, defined by the International Organization for Standardization and the International Electrotechnical Commission (ISO/IEC 9126-1, 2001), which decomposes quality into several characteristics, further divided into sub-characteristics (Figure 1). This standard defines internal metrics to be measured without having to operate the system and external metrics to be measured while testing or executing the system. The ISO/IEC 9126-1 definition of usability is concerned with attributes of the product that make it understandable, learnable, easy to use and attractive. ISO/IEC 9126-4 introduces the term "quality in use" as "The capability of the software product to enable specified users to achieve specified goals with effectiveness, productivity, safety and satisfaction in specified contexts of use" (ISO9126-4, 2004). Quality in use is the combined effect of the six categories of software quality when the product is in use. The objective is to achieve quality in use, both for the end user and the support user.

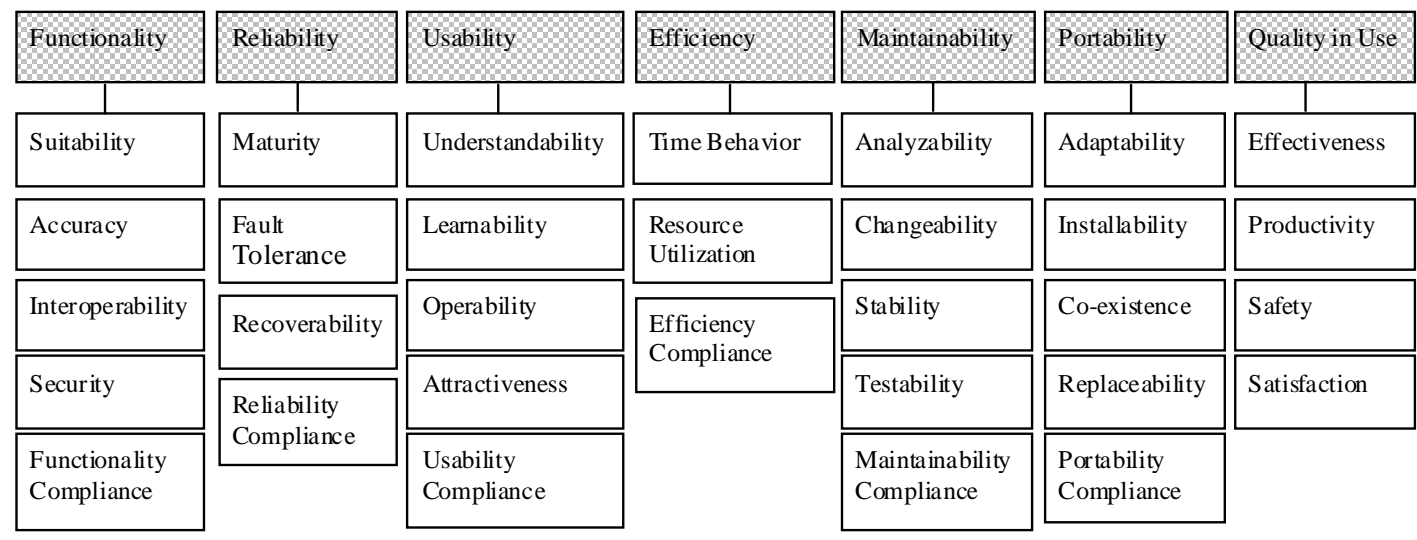

Figure 1: ISO/IEC 9126 Quality Characte ris tics and Sub-characteristics

Abran et al. (2003) proposed an enhanced model integrating together the ISO 9241-11 and 9126 standards, including sub-characteristics like effectiveness, security and satisfaction, which can be used as input to the next ISO review of these normative models.

The usability characteristic is also defined in the field of interactivity in Human-ComputerInterface (HCI), as an attribute that guides how to design an information system, ensuring that it 
is easy to use a system with a given level of functionality. This will lead to the fit of user' needs, which include the user's perceptions about the system, the mental effort needed, the ease of use and satisfaction (Te'eni et al., 2007).

According to Folmer and Bosch (2004), there are some reasons for this inconsistency in usability sub-characteristics definitions: (1) some authors use different names for the same attribute, such as memorability and learnability; (2) authors have different opinions on what they consider to be a useful usability attributes; (3) authors use different ways of combining attributes which compose usability.

From a practical viewpoint, it is important to define usability so that it can be measured.

ISO 9126 standard is the only approach to usability that recognizes usability to be a quality attribute of a product that is also influenced by other quality attributes (Folmer \& Bosch, 2004). Its enlargement to ISO/IEC 9126-4 suggests metrics for effectiveness, productivity, satisfaction and safety that can be used for this purpose.

\section{Usability in Mobile-Wireless Information Systems}

Mobility influences on ISO/IEC 9126 qua lity characteristics, and especially on the usability characteristic. One of the reasons is the operation of the system using mobile devices, because of the following motives:

- Technical limitations: small memories (the amount of information stored on it cannot be large), short battery life (the continuous period of work cannot be long) and limited calculation and computation capabilities.

- Wide variety of devices, possessing different characteristics, which the application must be adaptable to all of them (Brady, 2004).

- Uncomfortable use of devices: tiny screens, which restrict the amount of data displayed, and small keyboards that are difficult to operate.

The use of handheld devices can arise security, privacy and confidentiality problems (Di Pietro \& Mancini, 2003; Herzberg, 2003) when lost, due to possible unauthorized access to sensitive data. These problems are not dealt in this paper since they are not part of the usability quality characteristic, but are part of the functionality quality characteristic.

Relying on wire less networks affects on usability in some ways, for example:

- The network enables using automatic location information, instead of inserting information by the user.

- The bandwidth of the wire less network is relatively narrow, so the amount of data to be transferred must be limited.

Usability is one of the most important characteristics when targeting systems to wide audiences, that need to operate an intuitive system, without direct training and support.

Mobile users may not be able to concentrate on the system use, so the application should not be complicated, the input must be easy to insert, intuitive and simplified by using location aware functions (Terrenghi et al., 2005). Since mobile applications may be used while driving or walking, tasks which need the user attention, the application manipulation must be simple and intuitive, enforcing safety. Moreover, the noisy surroundings (when operating the system while on a street or public environments) may distract the user and cause input errors, inaccuracy and slowness. The operability sub-characteristic is affected mainly by the mobile device attributes: screen size, keyboard or numeric pad, etc., which restrict input and output interaction possibilities. On 
the other hand, the ability to reach the relevant data "any place any time" enlarges the system attractiveness.

\section{How to Measure Usability}

Mobile-wireless information systems must be measured, first, on the basis of traditional systems metrics, e.g. ease of maintainability, minimum complexity, lack of faults, mean time between failures (MTBF), etc., which are the fundamental metrics for all information systems. Furthermore, they must be measured according to internet systems metrics, e.g. no broken links, ease of navigation, etc. In addition, they need to be measured with special targeted mobile-wire less metrics (Spriestersbach \& Springer, 2004), which need to quantify the following questions:

- To what degree is the screen over-loaded and diminishes the application understandability?

- Are there specific menus for each possible operation?

- Are the buttons which operate each option clear enough?

- Is the help function for tasks easy to find?

- Is the application configurable according to user and device?

- Do the input fields have default values or choices instead of textual input, in order to minimize errors?

- Does the system use location aware functions, in order to minimize inputs?

- Is the length and format of the outputs optimized to screen size?

\section{Definition of New Usability Metrics}

The definition of new metrics to quantify the usability quality characteristic of mobile information systems is based on Gafni's (2008) research process, which consists of several phases:

(1) Detection of quality problems and risks that outcome from the architectures and protocols of mobile-wire less information systems and influence on usability (Asunmaa et al., 2002; Green, 2003; Huber, 2004; Tarasewich, 2003; Varshney \& Vetter, 2002; Vaughan-Nichols, 2004).

(2) Identification of objects (clustered into four entities: device, application, architecture and user), which were decomposed into measurable attributes (ISO/IEC 15939, 2002) and assigned a unit measure and a scale, according to its meaning (Kitchenham et al., 1995).

(3) Definition of metrics, methods for the measuring process with specific formulas, (ISO/IEC $15939,2002)$ to allow objective measurement of usability in mobile-wire less information systems.

(4) Metrics theoretical and empirical validation.

The new defined usability metrics can be mapped in two different viewpoints:

- As a matrix which displays the usability metrics according to the specific problems in mobile-wireless information systems. Table 1 presents this viewpoint mapping.

- As a hierarchy starting from the usability quality characteristic, describing which metrics quantify the degree of quality for each sub-characteristic. This is shown in Figure 2.

The new metrics are defined in Table 2. 
Table 1: Usability metrics mapped according to mobile-wire less problems

\begin{tabular}{|c|c|c|c|c|c|c|c|c|c|c|c|c|c|c|c|c|}
\hline Source of problems: & \multicolumn{5}{|c|}{ Network } & \multicolumn{6}{|c|}{ Device } & \multicolumn{5}{|c|}{ Mobility } \\
\hline Type of problem & $\begin{array}{l}0 \\
3 \\
0 \\
\vdots \\
z\end{array}$ & 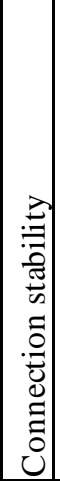 & $\begin{array}{l}3 \\
0 \\
0 \\
0 \\
0\end{array}$ & 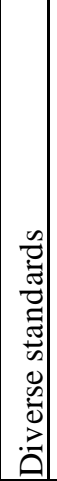 & $\begin{array}{l}n \\
\overline{0} \\
0 \\
0 \\
0 \\
00 \\
000\end{array}$ & $\begin{array}{l}0 \\
0 \\
0 \\
0 \\
0 \\
0 \\
0 \\
0 \\
0 \\
.0 \\
.0 \\
.0 \\
>\end{array}$ & $\begin{array}{l}\text { D } \\
0 \\
0 \\
0 \\
0 \\
0 \\
0\end{array}$ & 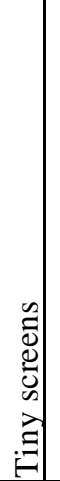 & 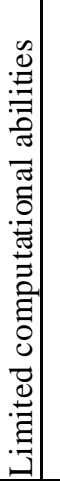 & 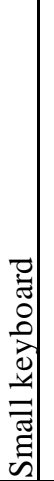 & 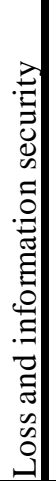 & 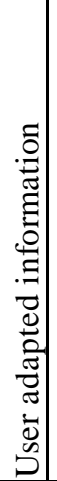 & 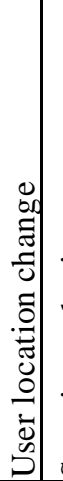 & 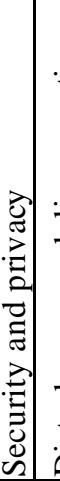 & 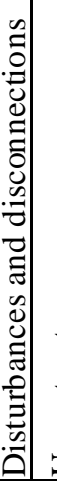 & 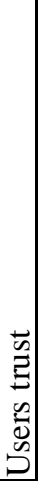 \\
\hline Display load & & & & & & & & $\mathrm{X}$ & & & & & & & & \\
\hline Clarity of operation possibilities & & & & & & & & $\mathrm{X}$ & & & & & & & & \\
\hline Comp leteness of operation menu & & & & & & & & & & $\bar{X}$ & & & & & & \\
\hline Display self-adjustment possibilities & & & & & & & & $\bar{X}$ & & & & $\mathrm{X}$ & & & & $\mathrm{X}$ \\
\hline Messages conciseness & $\mathrm{X}$ & & & & $\mathrm{X}$ & & $\mathrm{X} \mid$ & $\mathrm{X}$ & & & & & & & & \\
\hline Ease of input entering & & & & & & & & & & $\mathrm{X}$ & & & & & & \\
\hline Ease of output use & & & & & $\mathrm{X}$ & & & $\mathrm{X}$ & & & & & & & & \\
\hline Parameters self-adjustment possibilities & $\mathrm{X}$ & & & & $\mathrm{X}$ & & & & & $\bar{X}$ & & $\bar{X}$ & & & & \\
\hline Ease of use - displays per output & $\mathrm{X}$ & $\mathrm{X}$ & $\mathrm{X}$ & & $\mathrm{X}$ & & & & & & & & & & \begin{tabular}{l|l}
$\mathrm{X}$ & $\mathrm{x}$ \\
$\mathrm{n}$
\end{tabular} & $\bar{X}$ \\
\hline Ease of use - displays per task & $\mathrm{X}$ & $\mathrm{X}$ & & & $\bar{X}$ & & & $\bar{X}$ & $\bar{X}$ & & & & & & \begin{tabular}{l|l}
$X$ \\
$X$
\end{tabular} & $\bar{X}$ \\
\hline Tasks based on user location & & & & & & & & $\mathrm{X}$ & & & & $\mathrm{X}$ & $\mathrm{X}$ & & & \\
\hline
\end{tabular}

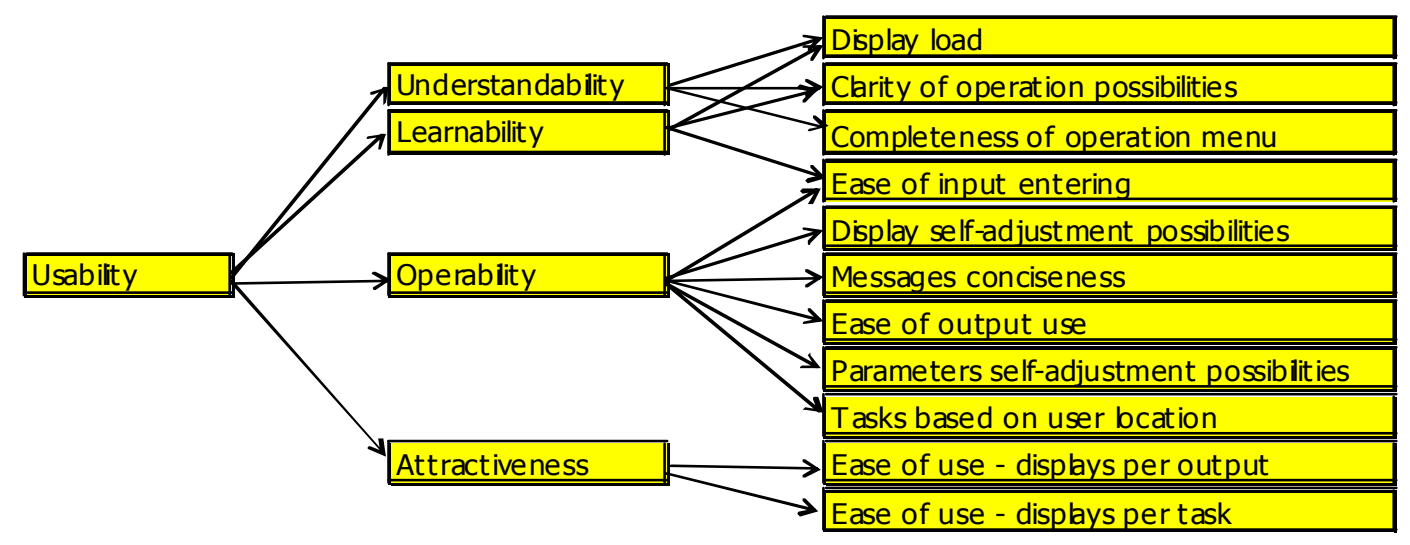

Figure 2: Metrics mapped according to us ability characte ris tic and sub-characteristics 
Table 2: Us ability Quality Metrics for Mobile-Wire less Information Sys te ms

\begin{tabular}{|c|c|c|}
\hline Metric Name & Metric purpose & Method of calculation \\
\hline Display load & $\begin{array}{l}\text { Measures the burden degree of } \\
\text { the displays. Because of the } \\
\text { screen's size, the understandabil- } \\
\text { ity is lower when the display is } \\
\text { overloaded. }\end{array}$ & $\begin{array}{l}\text { Calculate ratio between display size } \\
\text { and device screen size, for each dis- } \\
\text { play in system. Distribute ratios to } \\
\text { inversed weighted categories, and cal- } \\
\text { culate weighted average. }\end{array}$ \\
\hline $\begin{array}{l}\text { Clarity of operation } \\
\text { possibilities }\end{array}$ & $\begin{array}{l}\text { Measures the degree of clarity of } \\
\text { the possible operations in screen, } \\
\text { thus the user performs the right } \\
\text { activity. }\end{array}$ & $\begin{array}{l}\text { Observe new users' operations, ac- } \\
\text { cording to a pre-written scenario, and } \\
\text { count the number of right and wrong } \\
\text { actions. }\end{array}$ \\
\hline $\begin{array}{l}\text { Completeness of } \\
\text { operation menu }\end{array}$ & $\begin{array}{l}\text { Measures the degree of com- } \\
\text { pleteness of menus possibilities. }\end{array}$ & $\begin{array}{l}\text { Count the number of continuation pos- } \\
\text { sibilities in each display, and compare } \\
\text { to actual possibilities in menu. }\end{array}$ \\
\hline $\begin{array}{l}\text { Display self- } \\
\text { adjustments possibili- } \\
\text { ties }\end{array}$ & $\begin{array}{l}\text { Measures the degree in which a } \\
\text { user can adapt the displays of the } \\
\text { system to his/her needs. }\end{array}$ & $\begin{array}{l}\text { Count the percentage of displays } \\
\text { which can be self-adjusted. }\end{array}$ \\
\hline $\begin{array}{l}\text { Messages } \\
\text { conciseness }\end{array}$ & $\begin{array}{l}\text { Measures the conciseness of op- } \\
\text { erational and error messages. } \\
\text { This save place in memory and } \\
\text { the messages are easy to read } \\
\text { from screen. }\end{array}$ & $\begin{array}{l}\text { Calculate ratio between message size } \\
\text { and maximum lines in screen. Distrib- } \\
\text { ute ratios to inversed weighted catego- } \\
\text { ries, and calculate weighted average. }\end{array}$ \\
\hline $\begin{array}{l}\text { Ease of input } \\
\text { entering }\end{array}$ & $\begin{array}{l}\text { Measures the ratio of easy to fill } \\
\text { input fields, like usage of default } \\
\text { values, list of values or self- } \\
\text { completing fields. }\end{array}$ & $\begin{array}{l}\text { Count number of closed input fields, } \\
\text { default value fields and self- } \\
\text { completing fields. Calculate ratio be- } \\
\text { tween counted fields and total of input } \\
\text { fields. }\end{array}$ \\
\hline Ease of output use & $\begin{array}{l}\text { Measures the suitability between } \\
\text { length of outputs and device } \\
\text { screen size. }\end{array}$ & $\begin{array}{l}\text { Calculate average displays for mes- } \\
\text { sage. Count number of outputs need- } \\
\text { ing leafing, by checking ratio between } \\
\text { number of lines in output message and } \\
\text { number of lines in screen. }\end{array}$ \\
\hline $\begin{array}{l}\text { Parameters self- } \\
\text { adjustments } \\
\text { possibilities }\end{array}$ & $\begin{array}{l}\text { Measures the degree in which the } \\
\text { system can be adjusted to the us- } \\
\text { er's needs. }\end{array}$ & $\begin{array}{l}\text { Calculate the percentage of self- } \\
\text { adjustment parameters implemented in } \\
\text { the system. }\end{array}$ \\
\hline $\begin{array}{l}\text { Ease of use - } \\
\text { displays per output }\end{array}$ & $\begin{array}{l}\text { Measures the degree in which the } \\
\text { system performs minimum inter- } \\
\text { actions. }\end{array}$ & $\begin{array}{l}\text { Count the number of times the user } \\
\text { enters inputs to the system and wait } \\
\text { for response, till receiving the final } \\
\text { output. }\end{array}$ \\
\hline
\end{tabular}




\begin{tabular}{|l|l|l|}
\hline Metric Name & Metric purpose & Method of calculation \\
\hline $\begin{array}{l}\text { Ease of use - displays } \\
\text { per task }\end{array}$ & $\begin{array}{l}\text { Measures the number of screens } \\
\text { involved in one task. The effec- } \\
\text { tiveness and usability is greater } \\
\text { when the system is easier to op- } \\
\text { erate. }\end{array}$ & $\begin{array}{l}\text { Calculate number of iterations be- } \\
\text { tween user and system, till end of task. }\end{array}$ \\
\hline $\begin{array}{l}\text { Tasks based on user } \\
\text { location }\end{array}$ & $\begin{array}{l}\text { Measures the degree of usage of } \\
\text { task based on user location, to } \\
\text { minimize inputs. }\end{array}$ & $\begin{array}{l}\text { Count the tasks where user location } \\
\text { was implemented, and compare to to- } \\
\text { tal possible tasks. }\end{array}$ \\
\hline
\end{tabular}

\section{Validation of New Metrics}

Each metric defined by this research was validated theoretically and empirically at least by one of four different experiments performed in diverse technologies and devices, such as cellular phones and Personal Digital Assistants devices (examples of different displays can be seen in Figure 3):

1. The "PDA" experiment was performed on a system developed by Dooblo, a commercial company. The system allows conducting surveys on a PDA infrastructure. This system contains five different surveys, each including several displays.

2. The "Cellular" experiment was performed using a simulation system developed specifically for this research. This system simulates a cellular phone application. This application allows technic ians to service customers at home, per customers' complaints; that they generated via the cellular phone. This system was developed twice, a "high quality" system and a "low quality" system, which enabled comparisons.

3. The "Where is the Child" experiment was performed using a service provided by a major mobile phone company, which enables a parent to receive information, over the cellular phone, using GPS and cellular infrastructure, about the location of the ir child.

4. The "Electronic Mail" experiment was performed in parallel in two different environments, in order to compare them, and on a third environment, not wire less and not mobile, as a reference point:

a. Electronic Mail on a PDA environment, based on Microsoft Outlook.

b. Electronic Mail on a cell phone, based on a service supplied by a major mobile phone company, which was developed based on Microsoft Outlook Express.

c. Electronic Mail on a desktop computer, based on Microsoft Outlook Express. 


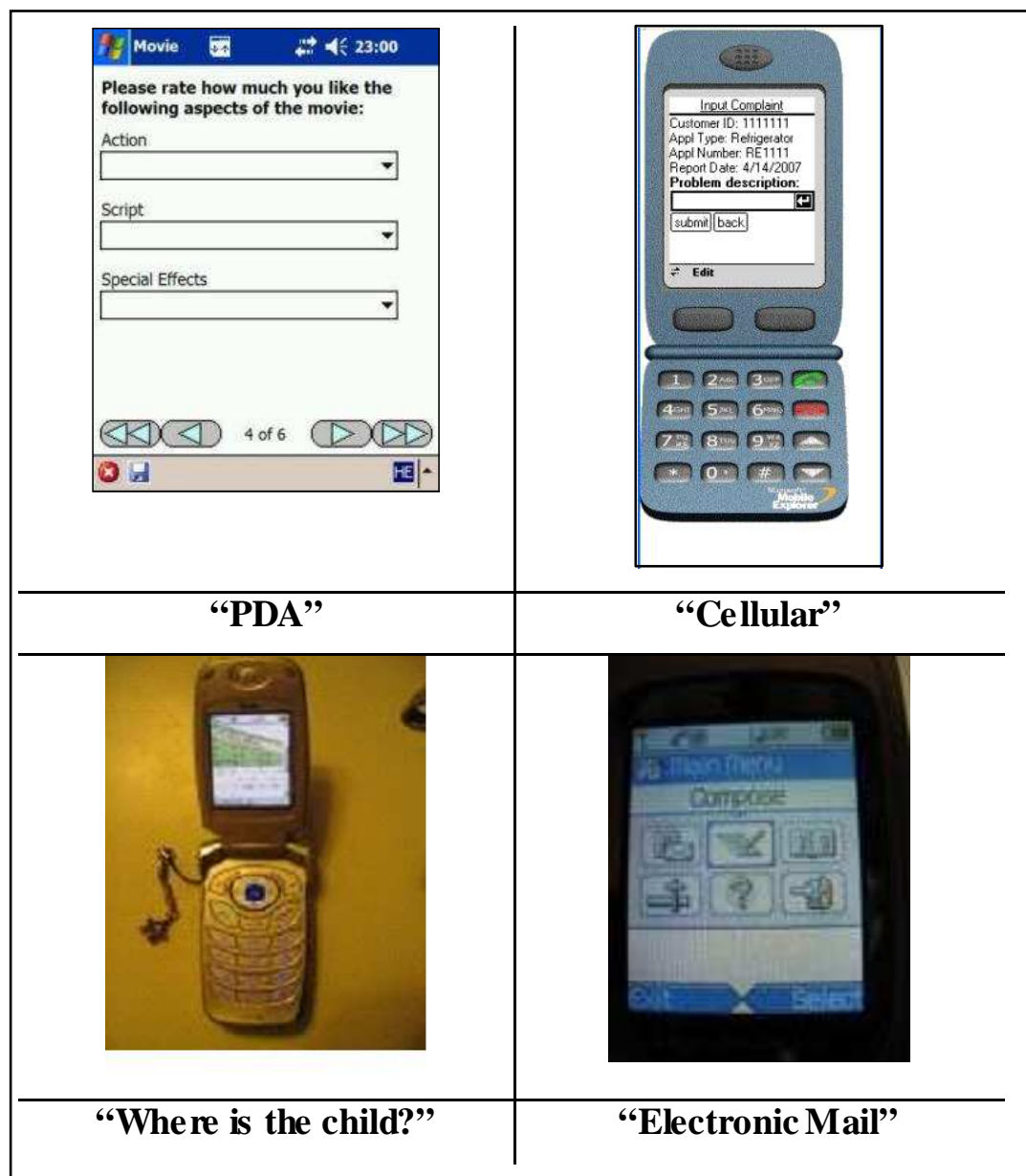

Figure 3: Examples of displays in the diffe rent experiments

The aim of the experiments was to validate that the metrics behave in a consistent and logical mode, for example, by showing that the value of the metric grows when quality increases, and vice versa. Thus, the metrics are a solid base to rely on, when quantifying the quality of these systems. The values of the metrics were calculated according to the "Method of Calculation" explained in Table 2 . Table 3 summarizes the validation of the usability metrics.

Table 3: Usability Quality Metrics Validation

\begin{tabular}{|l|l|l|}
\hline Metric Name & Validated in expe riment & Result of validation \\
\hline Display load & $\begin{array}{l}\text { "PDA" experiment } \\
\text { "Cellular" experiment }\end{array}$ & $\begin{array}{l}\text { For less loaded displays the metric value } \\
\text { received was higher, i.e., the displays of } \\
\text { the "Flight" survey which are the less } \\
\text { loaded, got a metric value of 1, the highest } \\
\text { possible. (Figure 4). }\end{array}$ \\
\hline
\end{tabular}




\begin{tabular}{|c|c|c|}
\hline Metric Name & Validated in experiment & Result of validation \\
\hline $\begin{array}{l}\text { Clarity of operation } \\
\text { possibilities }\end{array}$ & $\begin{array}{l}\text { "PDA" experiment } \\
\text { "Cellular" experiment }\end{array}$ & $\begin{array}{l}\text { The value received was higher when possi- } \\
\text { bilities were clearer, so the user made few- } \\
\text { er mistakes. }\end{array}$ \\
\hline $\begin{array}{l}\text { Completeness of } \\
\text { operation menu }\end{array}$ & $\begin{array}{l}\text { "Electronic Mail" } \\
\text { experiment }\end{array}$ & $\begin{array}{l}\text { None of the systems had fully completed } \\
\text { menus, but the value received was higher } \\
\text { for the system most completed. }\end{array}$ \\
\hline $\begin{array}{l}\text { Display self- } \\
\text { adjustments possibili- } \\
\text { ties }\end{array}$ & $\begin{array}{l}\text { "Electronic Mail" } \\
\text { experiment }\end{array}$ & $\begin{array}{l}\text { The two mobile systems had same number } \\
\text { of displays with self adjustments possibili- } \\
\text { ties, but less, compared to the desktop sys- } \\
\text { tem. }\end{array}$ \\
\hline $\begin{array}{l}\text { Messages } \\
\text { conciseness }\end{array}$ & $\begin{array}{l}\text { "PDA" experiment } \\
\text { "Cellular" experiment }\end{array}$ & $\begin{array}{l}\text { Surveys, in which the messages were } \\
\text { shorter in proportion with display, got a } \\
\text { higher metric value. }\end{array}$ \\
\hline $\begin{array}{l}\text { Ease of input } \\
\text { entering }\end{array}$ & $\begin{array}{l}\text { "PDA" experiment } \\
\text { "Cellular" experiment }\end{array}$ & $\begin{array}{l}\text { For surveys where the ratio of "closed" } \\
\text { questions was higher, the value received } \\
\text { was higher, as shown in Figure } 5 .\end{array}$ \\
\hline Ease of output use & $\begin{array}{l}\text { "PDA" experiment } \\
\text { "Cellular" experiment }\end{array}$ & $\begin{array}{l}\text { When the number of leafing needed to see } \\
\text { all the output is greater, the value of the } \\
\text { metric received was smaller (Figure 6). }\end{array}$ \\
\hline $\begin{array}{l}\text { Parameters self- } \\
\text { adjustments } \\
\text { possibilities }\end{array}$ & $\begin{array}{l}\text { "Electronic Mail" } \\
\text { experiment }\end{array}$ & $\begin{array}{l}\text { The two mobile systems were compared to } \\
\text { the desktop system. The PDA system had } \\
\text { more self-adjustments possibilities, and } \\
\text { accordingly got a higher value (Figure 7). }\end{array}$ \\
\hline $\begin{array}{l}\text { Ease of use - } \\
\text { displays per output }\end{array}$ & $\begin{array}{l}\text { "PDA" experiment } \\
\text { "Cellular" experiment }\end{array}$ & $\begin{array}{l}\text { Outputs which consist in less displays, got } \\
\text { a higher value than outputs which needed } \\
\text { more iterations. }\end{array}$ \\
\hline $\begin{array}{l}\text { Ease of use - displays } \\
\text { per task }\end{array}$ & $\begin{array}{l}\text { "PDA" experiment } \\
\text { "Cellular" experiment }\end{array}$ & $\begin{array}{l}\text { When the number of iterations needed to } \\
\text { finish a task is greater, the value of the me- } \\
\text { tric received was smaller. }\end{array}$ \\
\hline $\begin{array}{l}\text { Tasks based on user } \\
\text { location }\end{array}$ & $\begin{array}{l}\text { "Where is the Child" } \\
\text { experiment }\end{array}$ & $\begin{array}{l}\text { The whole purpose of this system is to find } \\
\text { user location, so in this case the metric re- } \\
\text { ceived the highest value. The user does not } \\
\text { need to insert the location. }\end{array}$ \\
\hline
\end{tabular}

The theoretical proof and the empirical experiments successfully validated the new metrics defined in this research. This paper focuses on the metrics development process, therefore the validation results are detailed only for the above example metrics. 


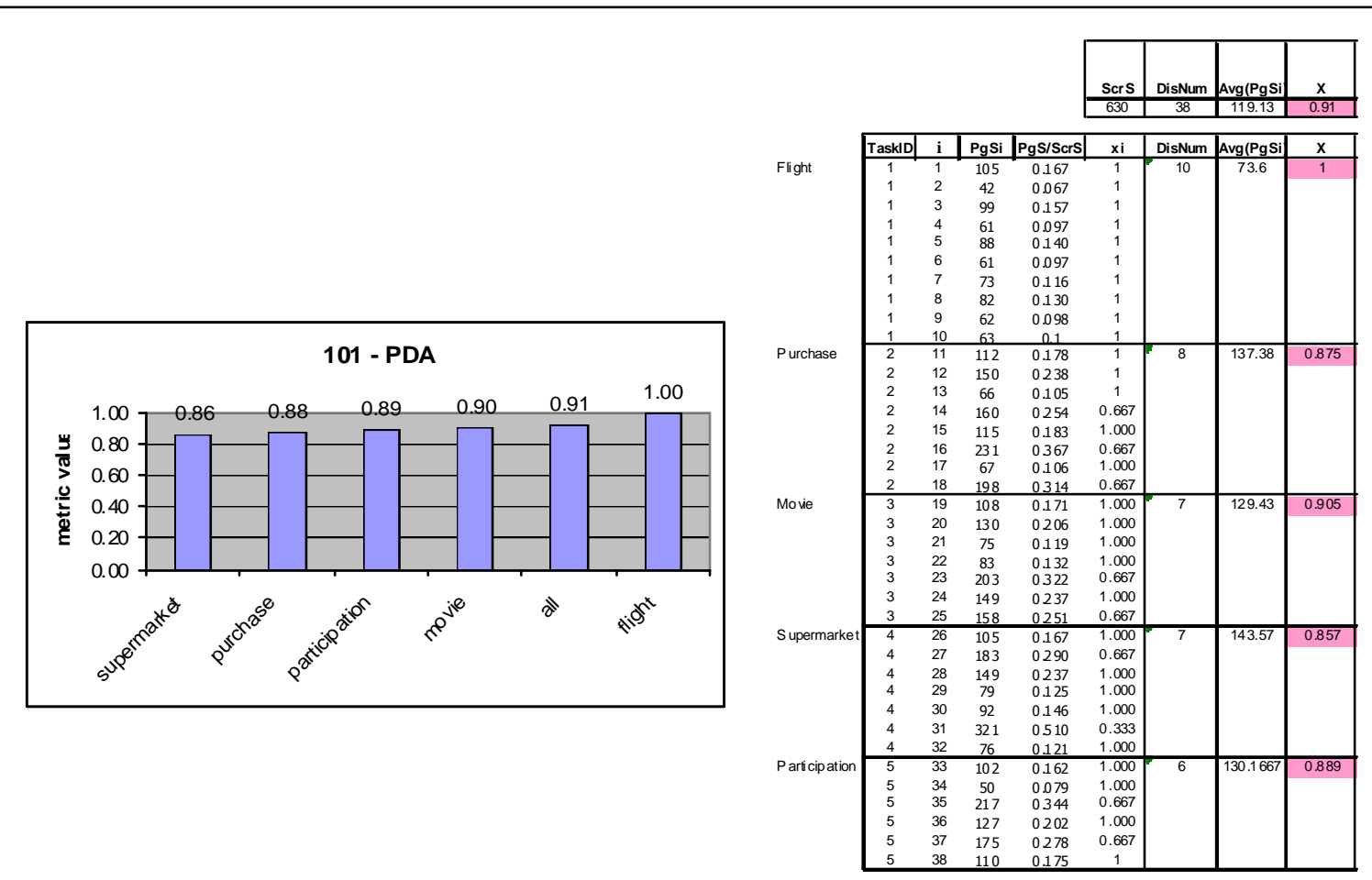

Figure 4: Validation of "Dis play load" me tric in "PDA" experiment

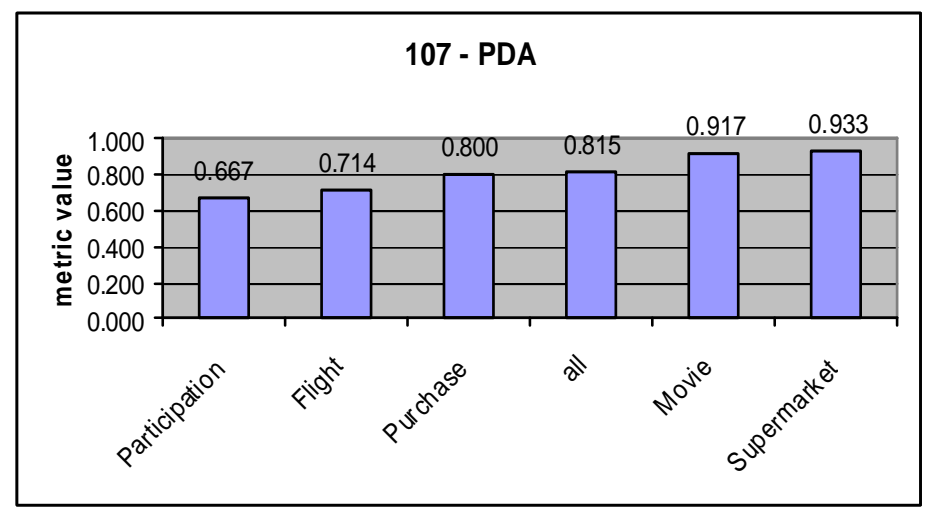

Figure 5: Validation of "Ease of input ente ring" metric in "PDA" experiment 


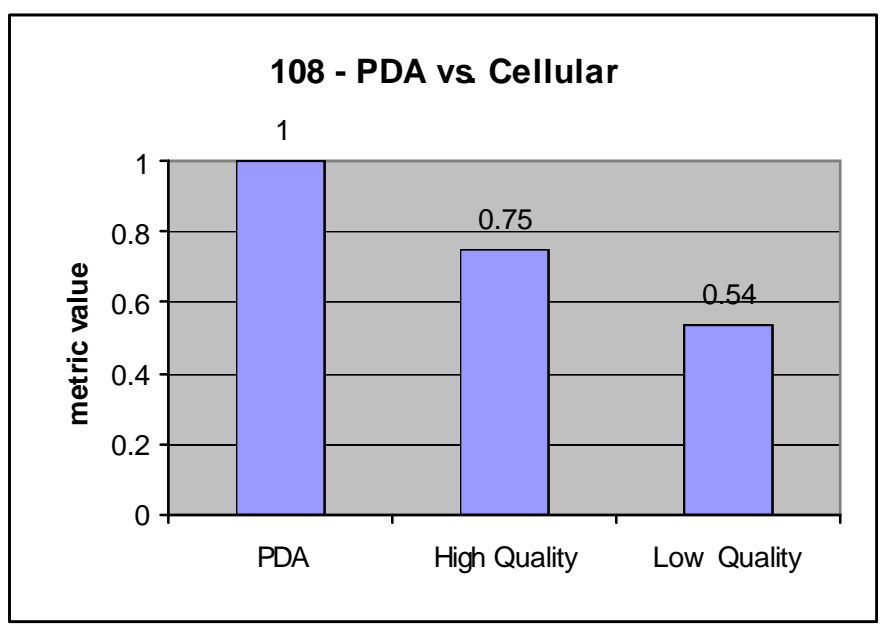

Figure 6: Validation of "Ease of output use" metric in "Cellular" and "PDA" expe riments

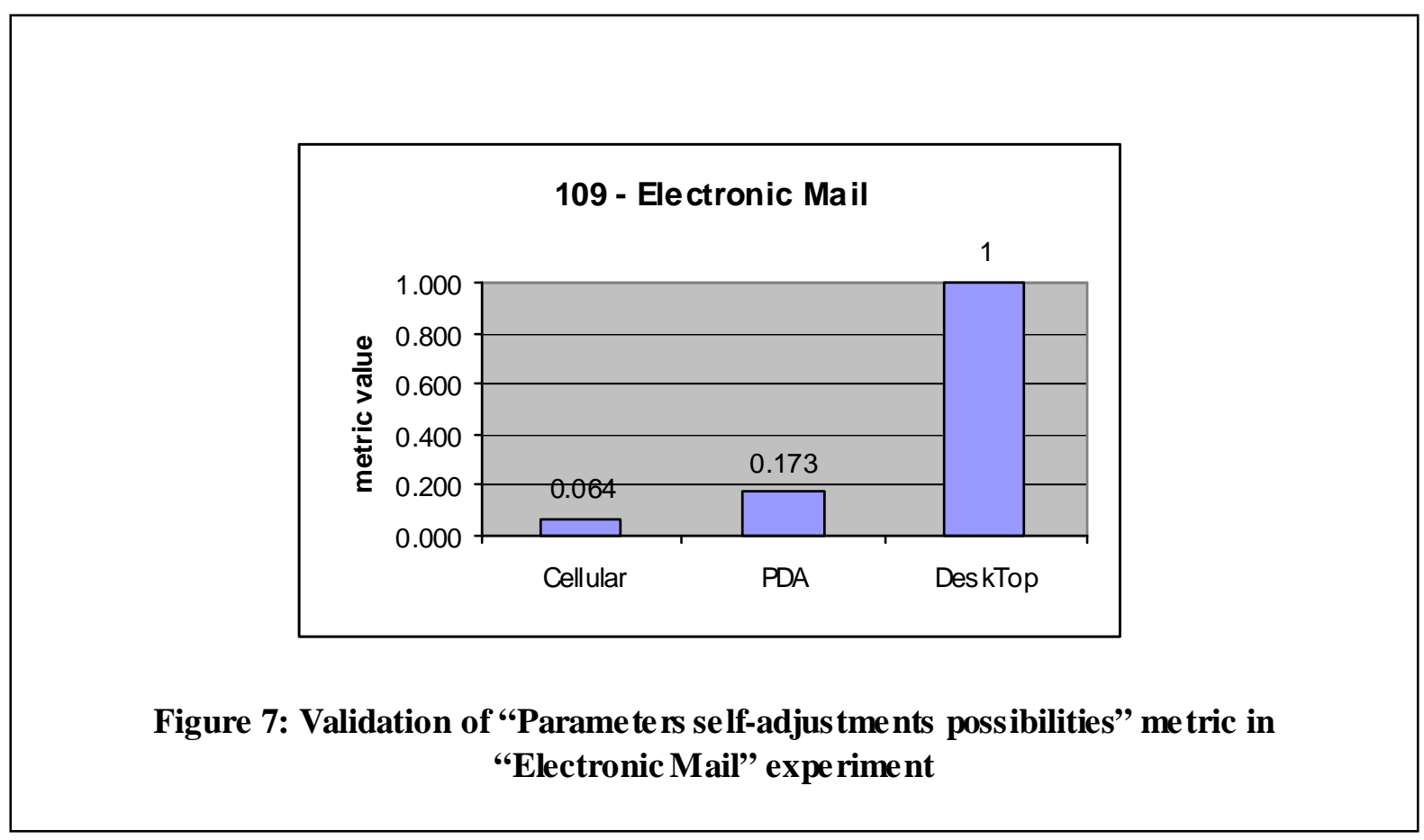




\section{Summary}

This paper introduced the usability quality characteristic, which is part of the definition of quality of information systems, although there is no consensus about its decomposition into subcharacteristics.

The degree of usability is affected when operating mobile-wireless information systems. These systems are activated through end devices, such as cellular phones and Personal Digital Assistance devices, which include a screen and displays. These technologies state new quality problems and challenges, especially because of the use of small devices with tiny screens, the difficulty to operate and the use during mobility.

Therefore, there is a need to measure the usability characteristic, in order to define the level of quality of such information systems. Metrics to measure the usability of such systems were developed methodologically and were validated theoretically and empirically. The metrics were mapped in two different viewpoints, covering the usability sub-characteristics on one hand, and the system problems on the other hand. These metrics enable objective quality evaluation and comparison of mobile-wire less information systems.

These metrics are useful when the quality level of a mobile-wireless information system must be analyzed, quantified or defined, for example when comparing two proposed systems, or when a system has to be developed or bought. When the metrics are used to compare systems, the higher the metric value, the higher the system's quality. However, when only one system has to be measured, the metrics need an external value to compare to. These values can be defined in advance according to the requirements of the system.

The purpose of the experiments was to validate the definition of the metrics, and this is the reason that performing them on small samples was sufficient. The experiments can be enhanced with extended samples, using different kinds of devices and more applications.

\section{References}

Abran, A., Khelifi, A., Suryn, W.,\& Seffah, A.(2003). Consolidating the ISO usability models. Proceedings of 11 th International Software Quality Management Conference (Springer), April 23 - 25, 2003. Glasgow, Scotland, UK

Asunmaa, P., Inkinen, S., Nykänen, P., Päivärinta, S., Sormunen, T., \& Suoknuuti, M. (2002). Introduction to mobile internet technical architecture. Wireless Personal Communications, 22, 253-259.

Bevan, N. (2001). International standards for HCI and usability. International Journal of Human Computer Studies, 55(4), 533-552.

Boeh m, B. W., Brown, J. R., Kaspar J. R., Lipow M., \& McCleod, G. (1978). Characteristics of software quality. Amsterdam: North Holland.

Brady, A., Conlan, O. \& Wade, V. (2004). Dynamic composition and personalization of PDA-based eLearn ing - Personalized mLearning. In G. Richards (Ed.), Proceedings of World Conference on ELearning in Corporate, Government, Healthcare, and Higher Education 2004, Chesapeake, VA: AACE, 234-242.

Calero, C., Ruiz, J., \& Piattini, M. (2004). A web metrics survey using WQM. Proceedings ICWE 2004, LNCS 3140, Springer-Verlag Heidelberg , 147-160.

Covella, G., \& Olsina, L. (2006). Assessing quality in use in a consistent way. Proceedings of the 6th International Conference on Web Engineering, ICWE'06, Palo Alto, California, USA, 1-8.

Di Pietro, R., \& Mancini, L.V. (2003). Security and privacy issues of handheld and wearable wire less devices. Communications of the ACM, 46(9), 74-79. 
Folmer,E., \& Bosch, J. (2004). Architecting for usability: A survey. The Journal of Systems and Software, 70(1-2), 61-78.

Gafni, R. (2008). Frame work for quality metrics in mobile-wireless information systems. Interdisciplinary Journal of Information, Knowledge, and Management, 3, 23-38.

Green, R. (2003). Wap 2.0: What is it? Wap 2.0 is coming, sooner than you might think, and it's going to change everything. Wireless Business and Technology, 3(6), 34-38.

Herzberg, A. (2003). Pay ments and banking with mobile personal devices. Communications of the ACM, 46(5), 53-58.

Huber, J. F. (2004). Mobile next-generation networks. IEEE Multimedia, 11(1), 72-83.

IEEE Std 1061. (1992). IEEE standard for a software quality metrics methodology. New York: IEEE Computer Society Press.

ISO/IEC 15939. (2002). Software engineering - Software measurement process. Geneva, Swit zerland: International Organization For Standardization.

ISO/IEC 9126-1. (2001). Software engineering - Product quality - Part 1: Quality model. Geneva, Switzerland: International Organization for Standardization.

ISO/IEC 9126-4, (2004). Software engineering - Product quality - Part 4: Quality in use metrics. Geneva, Switzerland: International Organization for Standardization.

ISO 9241-11. (1998). Ergonomic requirements for office work with visual display terminals (VDTs) - Part 11: Guidance on usability. Geneva, Switze rland: International Organization for Standardization.

Kan, S. (2002). Metrics and models in software quality engineering (2nd ed.). Addison-Wesley.

Kitchenham, B., Pfleeger, S. L., \& Fenton, N. (1995). To wards a framework for software measurement validation. IEEE Transactions on Software Engineering, 21(12), 929-944.

Lau, J. (2006). The state of European enterprise mobility in 2006. Forrester Research.

Lee, P. (2003). Mobile data comes of age: Wireless is big, we know that, but how big? Wireless Business and Technology, 3(9), 16-18.

Lovell, C. (1995). Mobile data moves ahead. Telecommunications International, 29(8), 113-114.

Malladi, R., \& Agrawal, D. (2002). Current and future applications of mobile and wireless networks. Communications of the ACM, 45(10), 144-146.

McCall, J. A., Richards, P. K., \& Walters, G. F. (1977, Nov.). Factors in software quality. RADC TR-77369, Vols I, II, III', US Rome Air Development Center Reports NTIS AD/A-049-014, 015, 055.

Pandian, C. R. (2004). Software metrics: A guide to planning, analysis, and application. Auerbach Publications.

Schiller, J. (2000). Mobile communications. Addison-Wesley.

Seffah, A., \& Metzker, E. (2004). The obstacles and myths of usability and software engineering. Communications of the ACM, 47(12), 71-76.

Spriestersbach, A., \& Springer, T. (2004). Quality attributes in mobile web application develop ment. $L N C S$ 3009, Proceedings of PROFES, Berlin: Springer-Verlag, 120-130.

Stafford, T. F., \& Gillenson, M. L. (2003). Mobile commerce: What it is and what it could be. Communications of the ACM, 46(12), 33-34.

Sult, D., \& Lee, P. (2003). Data adoption - A global evaluation - Enterprise mobile. Deloitte Research. Retrieved Jan. 20, 2004, from www.dc.com/research

Tarasewich, P. (2003). Designing mobile commerce applications. Communications of the ACM, 46(12), 5760. 
Te'eni, D., Carey, J., \& Zhang, P. (2007). Human-computer interaction: Designing effective organizational information systems. Chichester: John Wiley.

Terho, M. (2002). Mobile web services and software quality. LNCS 2349, Proceedings of ESCQ, Berlin: Springer-Verlag, 2-6.

Terrenghi, L., Kronen, M., \& Valle, C. (2005). Usability requirements for mobile service scenarios. Proceeding of HCI International Conference, Las Vegas, USA, 1-10.

Varshney, U.; Vetter, R. (2002). Mobile co mmerce: Frame work, applications and networking support. Mobile Networks and Applications, 7, 185-198.

Vaughan-Nichols, S. J. (2004). Wireless middle ware: Glue for the mobile infrastructure. IEEE Computer, 37(5), 18- 20.

\section{Biography}

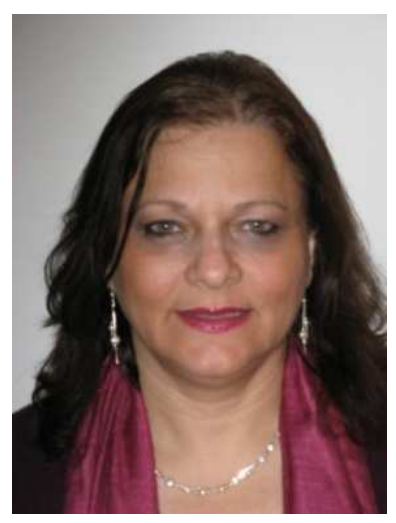

Dr. Ruti Gafni holds a $\mathrm{PhD}$ from Bar-Ilan University, Israel in the Business Administration School, focusing in Information Systems. She holds an M.Sc from Tel Aviv University and a BA(Cum Laude) in Economics and Computer Science from Bar-Ilan. She has more than 30 years of practical experience as project manager and analyst of information systems. She teaches in the Management and Economics MBA program, both at the Open University of Israel and at Netanya Academic College. 